OKULLARDA FARKLILIKLARIN ÖRGÜTSEL DOĞURGULARI: BİR ÖRNEKOLAY İNCELEMESI

\author{
THE ORGANIZATIONAL CONSEQUENCES OF DIVERSITY IN \\ SCHOOLS: A CASE STUDY
}

\title{
Hasan Basri MEMDUHOĞLU1
}

Özet: Bu araştırmanın genel amacl; liselerde çalışanlarla ilgili farklılıkların okullar için yarattığ 1 doğurgulara (olumlu ve olumsuz sonuçlar) ilişkin öğretmen ve yönetici görüşlerini belirlemektir. Tarama modelindeki araştırma verilerinin toplanmasında nitel bir yöntem olan vak'a (örnekolay) incelemesi kullanılmıştır. Bunun için çalışmada konuyla iloili okullarda yaşanan başarı ya da sorun hikâyeleri ile ilgili yönetici, öğretmen ve denetmenlerle görüşmeler yapılmış ve soruşturma dokümanları incelenmiştir. Çalışmada çalışanlara ait farklılıkların okullarda hem entelektüel gelişim, hem de okuldaki bazı sorunlara pratik çözümler getirme açısından önemli avantajlar sunduğu, ancak bunun yanında kimi sorunlara da neden olduğu sonucuna ulaşılmıştır.

Anahtar Kelimeler: Farklılık, Çeşitlilik, Farklılıkların yönetimi

\begin{abstract}
The general purpose of this research was to determine the views of teachers and administrators concerning the consequences arising from the diversity related to the employees at high schools. In data collection of the survey model research, case study a method of qualitative research was used. For this, in the study; administrators, teachers and supervisors were interviewed about experienced problems or success stories in the schools related to the issue and investigation documents were examined. In the study, it was precipitated that the differences pertaining to employees offered advantages in terms of bringing some practical solutions to both problems at schools and problems concerning intellectual development, but it was also understood they caused some problems.
\end{abstract}

Key Words: Diversity, diversity management.

\footnotetext{
${ }^{1}$ Yrd. Doç. Dr. Hasan Basri MEMDUHOĞLU, Van Yüzüncü Yıl Üniversitesi, Eğitim Bilimleri Bölümü, Eğitim Yönetimi Teftişi Planlaması ve Ekonomisi Bilim Dalı, hasanmemduhoglu@gmail.com
} 


\section{Giriş}

Dünyada hızla değişen demografik ve ekonomik yapılar, küresel etkileşim ve teknolojik gelişmeler örgütlerin felsefelerini, kültürlerini ve stratejilerini etkilemekte, örgütsel açıdan farklılıkları artırmaktadır. Küreselleşme ile gelen rekabete dayalı pazar sistemi ile beraber çalışan insanın yeterliklerinin yanında onu farklı kılan özellikler de önem kazanmaya başlamış ve bu durum bir zihniyet dönüşümüne yol açmıştır. Örgütte yaşanan bu zihniyet dönüşümünün rekabette esas unsur olarak insanı ön plana çıkarması ve merkeze koyması (Bhadury, Mighty ve Damar, 2000, 143) ile birlikte, yönetim tarzları ve insan ilişkilerinde yeni yaklaşımlara gereksinim duyulmaya başlanmış, hizmet ve üretimin en temel öğesi durumuna gelen insan kaynağının yönetimi de daha bir önem kazanmıştır. Bu bağlamda ortaya çıkan yeni yaklaşımlardan biri de farklllıkların yönetimidir.

Örgütler, coğrafi açıdan yayıldıkça ve işgücünün ülkeler arası serbest dolaşımı arttıkça daha geniş kimliklerle ve farklılıklarla etkileşim giderek daha kritik bir konu haline gelmekte ve bu durum işgücü kompozisyonunun sürekli olarak değişmesine yol açmaktadır (Ashkanasy, Hartel ve Daus, 2002, 308). Artık küreselleşen dünyada üretim ve tüketim sürecindeki tüm unsurlar (çalışanlar, müşteriler, paydaşlar, tedarikçiler vs.) kültürel farklılık ve çeşitlilik oluşturmaktadır (Zenger, 1995; akt.Muter, 1999).

İnsanlar, genellikle başkalarının dünyaya kendileri gibi baktığını, benzer değerlere sahip olduklarını ve aynı sebeplerle güdülendiklerini düşünürler. Oysaki çocukluktan beri kazanılan değerler ve davranışlar, yaşanılan yer ve yaşayış şekli, kişisel özellikler vb. nedenlerle insanlar farklı düşünebilmekte ve farklı davranmaktadır (Laçinler, 1997). Örgütlerde çalışanlar arasında görülebilen temel farklılık alanları (boyutları) şöyle sıralanabilir:

Demografik farklılıklar: Irk, milliyet, etnik köken, cinsiyet, yaş, deneyim, çalışanların doğdukları ya da aidiyet duydukları bölge/şehir ve fiziksel özellikler (vücutça işe uygunluk derecesi) gibi sabit ya da kalıcı özellikleri kapsar. Sosyo-kültürel farklılıklar: Din ve felsefi inanç, siyasi 
görüş, eğitim düzeyi, ekonomik durum, dünyayı algılama biçimi, kültürel altyapı, yaşam tarzı, gelenek, örf, adet ve değer yargıları gibi sahip olunan ve benimsenen değerlerdir. Bireysel özelliklerdeki farklıklılar: kişilik, fiziksel ve zihinsel yetenekler, bilgi ve beceri düzeyi, davranış stili, psikolojik, ruhsal ve duygusal yapı, kişisel kavramlaştırma ve duygusal uyumlama özellikleri şeklinde ele alınabilir

Bilge bir baba eş arayan oğluna şöyle öğüt verir: "Bulabildiğin kadar çok benzerliğiniz olmalı, çünkü nasıl olsa birçok farklılı̆̆ınız olacak". İnsanlar arasında farklılık doğaldır ve yaygındır. Her birey farklı demografik, bireysel ve sosyo-kültürel özelliklere ve değerlere sahiptir. Bu farklılıkların çeşitli örgütsel yansımaları, bireysel ve örgütsel yarar ve sakıncaları olabilmektedir. İşgücü farklılıkları örgütsel açıdan çeşitli avantajlar sağlarken aynı zamanda iyi yönetilmediğinde kimi sakıncalara da yol açabilmektedir. Bu açıdan farklılık, örgütler için hem bir avantaj hem de sorun çıkarıcı bir olgu olarak kendini gösterir. Bu avantaj ve sakıncaların bilinmesi önemlidir. Günümüzde örgütler, birçok konuda farklı özelliklere sahip kişilerin birlikte uyum içinde çalışmasını sağlamak durumunda kalmakta (McMahan, Bell ve Virick, 1998, 198), dolayısıyla çalışanların bireysel, sosyal ve kültürel farklılıklarına saygı duyma, bunları zenginlik olarak görerek örgütün amaçları doğrultusunda yönetme düşüncesi giderek önem kazanmaktadır (Muter, 1999). Bu bağlamda 1990’1 yıllardan itibaren insan kaynakları yönetimi araştırmacılarının "Farlılıkların Yönetimi" (Diversity Management) şeklinde yeni bir kavramsallaştırmaya gittikleri görülmüştür (McMahan, Bell ve Virick, 1998, 198). Farklılık yönetimi, çalışanlar arasındaki her türlü farklılığı tanımayıkabul etmeyi, onlara saygı duymayı, açık olmayı ve onları değerlendirmeyi içerir. Amaç tüm çalışanların ve örgütün gelişmesi için pozitif bir çalışma ortamı yaratmaktır (Riccucci, 1997; Rynes ve Rosen, 1995; Von Bergen, Soper ve Foster, 2000).

Diğer alanlarda olduğu gibi eğitim örgütlerindeki çalışanlar da farklı demografik, sosyal, kültürel ve bireysel özelliklere sahiptir ve bunların bireysel ve örgütsel amaçlar doğrultusunda iyi yönetilmesi önemlidir. Bu gerçeğe rağmen farklılıklar konusunda yurtdışında çok sayıda araştırma yapılmasına karşın (Richard, McMillian, Chandwick ve Dwyer, 2003; Maldonado, Dreachslin, Dansky, Souza ve Gatto, 2002; Cox 
ve Nkomo, 1990; Gentile, 1994; Cox, 1992; Gilbert ve Stead, 1999; Heilman, 1994; Demovsky ve Niemuth, 1999; Watson, Kumar ve Michaelson, 1993; Williams ve O'Reilly, 1998; Richard, 2000; Wright ve McMahan, 1992) bu konunun Türkiye'de ve özellikle eğitim alanında yeterince araştırılmadığ görülmektedir. Bu amaçla Türkiye'deki eğitim örgütlerinde farklılıklara ve farklılıkların örgütsel yansımalarına ilişkin bir çalışmanın yapılmasına gereksinim olduğu söylenebilir.

\section{Amaç}

$\mathrm{Bu}$ araştırmanın genel amacı; liselerde çalışanlarla ilgili farklılıkların okullarda yarattığı doğurgulara (olumlu ve olumsuz sonuçlar) ilişkin ögretmen ve yönetici görüşlerini belirlemektir.

\section{Yöntem}

Araştırma tarama modelindedir. Araştırma verilerinin toplanmasında nitel bir yöntem olan vak'a (örnekolay) incelemesi kullanılmıştır. Bunun için çalışmada konuyla ilgili okullarda yaşanan başarı ya da sorun hikâyeleri ile ilgili yönetici, öğretmen ve denetmenlerle görüşmeler yapılmıştır. Vak'a incelemeleri kişilerle görüşülerek ya da dokümanlar incelenerek elde edilen nitel verilere dayanmaktadır (Wochner, 1963, 99; Kaptan, 1991, 66-69; Punch, 2005, 145).

Araştırmanın hedef evrenini, Kayseri ve Van il merkezlerindeki kamu liselerinde görev yapan yönetici ve öğretmenler ile eğitim denetmenleri oluşturmaktadır. Hedef evren içinden illerin nüfusu ve lise sayıları dikkate alınarak Kayseri'de dört ve Van'da üç lisede görev yapan ikişer yönetici ve öğretmen ile her ilden üçer eğitim denetmeni çalışma grubuna alınmıştır. Böylelikle araştırmanın çalışma grubunda 14 okul yöneticisi, 14 öğretmen ve 9 eğitim denetmeni yer almıştır. Ancak bu görüşmelerde çalışma grubundaki katılımcıların anlattığı sorun ya da başarı hikâyelerinin kahramanları ve bu hikâyelerden etkilenen kişilerle de görüşülmeye çalışılmış, böylelikle çalışma grubu esnek tutulmuştur. 
Çalışmada ayrıca konuya ilişkin ortaya çıkan sorunlarla ilgili soruşturmalara konu olmuş durumların incelenmesi planlanmıştır. Bu soruşturmaların incelemesiyle daha derinlemesine bilgilere ulaşılması hedeflenmiştir. Ancak görüşmelerde konuya ilişkin soruşturmalara konu olan fazla vakaya ulaşılamamıştır. Hassas bir konu olan farklılıklara ilişkin yaşanan sorunların genelde soruşturmalara yansıtılmadığ nedenle sınırlı belge/doküman incelemesi yapılabilmiştir. Bunun yerine daha çok yönetici, öğretmen ve eğitim denetmenleri ile yapılan görüşmelerde okullarda konu ile ilgili yaşanan başarı ve sorun hikâyeleri ile ilgili değerlendirme yapılmıştır. Çalışmada çok sayıda vak'a (örnekolay /sorun ya da başarı hikâyesi) elde edilmiştir. Ancak bunlardan doğrulanamayan, basit ve küçük çaplı olan ve birbirine çok benzerlik gösteren örnekolaylar değerlendirme dışı tutulmuştur.

Araştırma verilerinin çözümlenmesinde, nitel bir analiz yöntemi olan "içerik analizi" kullanılmıştır. Yazılı ve sözlü materyallerin sistemli ve dizgesel bir analizi olan içerik analizi insanlarının söylediklerinin kodlanarak kategorileştirilmesi ve betimlenmesidir (Balc1, 2001, 209; Yildırım ve Şimşek, 2005, 227; Neuendorf, 2002, 1-9; Neuman, 2007, 663666). İçerik analizinin niceliksel ve niteliksel uygulamaları vardır. Niceliksel içerik analizinde ifadelerin (cümle) katılımcılar tarafından tekrarlanma sayıları (frekans) belirlenir. Niteliksel içerik analizinde ise, ifadeler, niteliklerine göre olumlu, olumsuz ve yansız olarak değerlendirilir. $\mathrm{Bu}$ çalışmada niteliksel betimsel içerik analizi kullanılmıştır. Buna göre görüşmelerde kasetlere kaydedilen ya da not tutulan hikayeler çözümlenerek yazılmış, daha sonra hikayeler olumlu (başarı hikayesi) ve olumsuz (sorun hikayesi) şeklinde kategorilendirilerek betimlenmiştir. Hikayeler verilirken, alıntı seçimi için çarpıcılık (farklı görüş), açıklayıcılık (temaya uygunluk), çeşitlilik ve uç örnekler ölçütleri dikkate alınmıştır (Carley, 1992, Akt. Finney ve Corbett, 2007; Ünver, Bümen, Başbay, 2010). Daha sonra görüşme yapılan yönetici, öğretmen ve eğitim denetmenlerinin ağzından aktarılarak betimlenen örnekolaylar tümevarım yöntemi ile yorumlanarak tartışılmış ve değerlendirilmiştir

\section{Bulgular}


Değerlendirmeye alınan örnekolaylar farklılıkların okul ve çalışanlar için yarattığı sonuçlar açısından olumlu ve olumsuz (başarı ve sorun hikayeleri) şekilde kategorilendirilerek verilmiştir. Örnek olaylar (hikayeler) görüşme yapılan yönetici, öğretmen ve eğitim denetmenlerinin ağzından aktarılarak sunulmuş ve bulgular betimlenmiştir. Daha sonra bu örnekolaylar genel olarak tartışılarak yorumlanmıştır.

\section{Olumlu Örnekolaylar (Başarı Hikâyeleri)}

Örnekolay 1 (Okul yöneticisi): Okulumuzda her yıl folklor ekibi kurulur. Bu ekip önemli günlerde ve yılsonlarında gösteriler yapar, ildeki yarışmalara katılır. İki yıl önce okulumuzun ekibi liseler düzeyinde il birincisi oldu. İlimizi temsilen bölge yarışmalarına katılmak üzere başka bir ile gitmesi gerekti. Folklor ekibini erkek bir öğretmen çalıştırmaktaydı. Ekipteki öğrencilerin il dışına bu öğretmenin sorumluluğunda gitmesi kararlaştırıldı. Öğrencilerin konaklayacakları yurt, ulaşım gibi durumları ayarlanırken bazı velilerin kız öğrencilerinin il dışına gitmelerine izin vermediklerini öğrendik. Bunca emek boşa gidecekti. Velilerle görüşüldü. Veliler, bir bayan öğretmenin ekibe eşlik etmesi koşuluyla buna izin vereceklerini belirttiler. Bunun üzerine okuldaki bir bayan öğretmen ekibe dâhil edildi ve yarışmaya giden ekibimiz oradan ikincilikle döndü.

Örnekolay 2 (Okul yöneticisi): Okul müdürü olarak benim için eğitim, öğretimden önce gelir. Eğitsel etkinliklerin öğrencilerin sosyalleşmelerinde ve yaşama uyum sağlamalarında önemli olduğunu düşünürüm. Bu nedenle okulumuzda münazara, folklor, şiir dinletileri, piyes, konuk davetleri, çevre gezileri, sosyal sorumluluk projeleri, kardeş okul uygulamaları, konferanslar, sportif gösteri ve yarışmalar, okul gazete ve dergileri, bilim, sanat ve eğlence şenlikleri gibi sosyal ve sportif etkinlikler düzenleriz. Bu etkinlikler ilgili alanda ilgisi ve yeterliliği olan öğretmenlerce koordine edilir. Ancak bazen edebiyat, sanat, bilim, çevre, spor, folklor gibi değişik alanlarda yetkinliği olan öğretmenlerin okulumuzda bulunmaması işimizi zorlaştırmaktadır. Nitekim en önemli sıkıntıyı ilgili konuda sorumluluk alacak yeterlik sahibi öğretmenlerin olmaması konusunda yaşıyoruz. Bundan dolayı bazen başka okullardaki 
öğretmenlerden destek talep ederiz ya da folklor gibi konularda ücret karşıllı̆ 1 dışarıdan birini görevlendiririz. Geçen yıl Milli Eğitim Müdürlüğünden bir konuda yeteneği olduğunu duyduğum bir öğretmenin okulumuza görevlendirmeyle atanması için talepte bulunmuştum. Kısaca farklı ilgi, yetenek ve yeterliklere sahip öğretmenlerin okulumuzda görev yapması, hem amaçlarımıza ulaşmamızı kolaylaştırır, hem de okulumuzun ve öğrencilerimizin gelişmesine daha çok katkı sağlar.

Örnekolay 3 (Öğretmen): Bir gün rehber öğretmen dokuzuncu sınıfta okuyan bir kız öğrenci ile ilgili görüşmek istediğini bildirdi. Rehber öğretmen kız öğrencinin genel durumu ve dersleri ile ilgili sıkıntılar tespit etmiş ve öğrenciyle görüşmüş. Öğrenci bu görüşmede bu sıkıntıların nedenlerini rehber öğretmenle paylaşmış. Ancak bazı özel nedenleri erkek olan rehber öğretmen erkek öğretmen erkek olduğu için kendisine anlatamayacağını belirtmiş. Benden bir bayan olarak görüşmemi istedi. Ben de rehber öğretmenin odasında görüştügüm kız öğrencinin bayanlara özgü özel durumlarına ilişkin ciddi sağlık sorunları yaşadığını öğrendim. Durumu ailesiyle görüşerek tedavi sürecinin başlatılmasını sağladık. Bu olaydan, bir okulda öğrencilerin farklı sorunlarına ve ihtiyaçlarına ilgi gösterebilecek farklı çalışanların olmasının ne kadar önemli olduğunu anladim.

Örnekolay 4 (Öğretmen): Okula yeni atanmıştım. Başka bir ildeki okuldan buraya gelmiştim. Dersimi işlerken aynı zamanda okul ortamını ve özellikle öğrencileri tanımaya çalışıyordum. Sınıf rehber öğretmenliği yaptığım sınıfta bir öğrencinin durumu dikkatimi çekiyordu. Derste genelde sessiz durur, derse pek katılmazdı. Teneffüslerde de bahçede çoğunlukla yalnız gezerdi. Bir gün kendisiyle görüştüm. Çok çekingen duruşu vardı. Doğudaki bir ilçeden iki yıl önce bu ile taşınmışlardı. Babası, bir tanıdıklarının inşaatında bekçilik yapıyormuş. Ailesiyle de görüşmek istediğimi söyledim. Babasının işten ayrılamadı̆̆ını söyledi. Ben de annesini çağırmasını istedim. Bundan hoşlanmadı. Siz bana söyleyin ben ileteyim dedi. Ama israr edince kabul etti. Ertesi gün çekingen tavırlarla bir kadın öğretmenler odasına geldi. Beni soruyordu. Kim olduğunu tahmin ettim. Ama birkaç kelimeden başka hiç Türkçe bilmiyordu. Ne yapacağımı bilemedim. Öğrenciyi tercümanlık yapması için çağırmayı düşündüm. Fakat öğrencinin evdeki aile içi durumunu konuşacaktım. Öğrencinin 
bundan incinebileceğini düşünerek bu fikrimden vazgeçtim. Diğer öğretmenlere sorunu paylaştım. Öğretmenlerden birinin doğulu olduğunu Kürtçe bilebileceğini söylediler. Ona gittim ve durumu paylaştım. Benimle veli arasında tercümanlık yaptı. Ailenin çok sıkıntılı yaşam hikâyesini öğrendik. Öğrenci için rehber öğretmenle iletişime geçtim ve okul yönetiminden destek aldım. Aile için de okul yönetimi ile işbirliği yaparak çeşitli kurumlarla iletişime geçtik. Eğer Kürtçe bilen öğretmen olmasaydı aileyle iletişim konusunda sıkıntı yaşayabilirdik.

Örnekolay 1, örnekolay 2, örnekolay 3 ve örnekolay 4'te görüldüğü gibi okullarda çalışanların farklılıkları, hem çalışanlar, hem de okul için avantaj sağlayabilmektedir. Birinci ve üçüncü örnekolaylarda cinsiyet, ikinci örnekolayda kişilik, yetenek, bilgi ve beceri düzeyi, dördüncü örnekolayda etnisite ve dil gibi çalışanlara ilişkin demografik, sosyo-kültürel ve bireysel özelliklerdeki farklıklılar, okullarda çeşitli sorunların çözümünde, farklı sosyal ve kültürel etkinliklerin başarı ile yürütülmesinde, öğrencilerin ve çalışanların gelişmesinde ve okulun amaçlarının gerçekleştirilmesinde etkili rol oynamaktadır.

\section{Olumsuz Örnekolaylar (Sorun Hikâyeleri)}

Örnekolay 5 (Okul yöneticisi): Geçen yıl okulumuza bir öğretmen atandı. Mesleğe yeni başlayan genç bir erkek öğretmendi. Giyimi, kulağına taktığı küpeleri, iletişimi ve rahatlığıyla yaşam tarzı oldukça farklıydı. Okul dışında şortla yürürken bu durumunun çevredekiler tarafından yadırgandığını, kendisine laf atıldığını ve birkaç kez birileriyle tartıştığını duymuştuk. Birkaç kez dersi olmayan günlerde bu şeklide okula da geldi. Kolları dövmelerle kaplıydı. Hemen dikkat çekiyordu. Bazı öğrenci velilerinden şikâyetler geldi. Bazı veliler bu öğretmenlerin kendi çocuklarının derslerine girmesini istemediklerini, gerekirse şikayetçi olacaklarını söylediler. Bunun üzerine okul yönetimi olarak öğretmenle konuştuk. Uygun bir dille durumu kendisine anlattık. Önceleri bunu kabullenmek istemedi, artık okula şortla gelmeyeceğini, ancak resmi gereklilikler dışında kimsenin özel yaşamına karışamayacağını söyledi. Fakat daha sonra bu konulara daha duyarlı davranacağını belirtti. Yine de zaman zaman bu durumdan kaynaklanan sorunlar yaşandı. 
Örnekolay 6 (Öğretmen): Her yıl olduğu gibi geçen yıl da okulumuza üniversiteden staj yapmak üzere son sınıf öğrencileri geldi. Bir süre sonra bazı öğrenciler arasında ideolojik tartışmalar yaşandı. Stajyer öğrenciler arasında bazı sorunlar yaşandı. Sonra bu tartışmalara bazı öğretmenler de taraf oldu. Bu durum kısa sürede 6-7 öğretmenin katıldığ bir ideolojik gruplaşmaya neden oldu. Okul yönetimi üniversiteyle iletişime geçerek olaylara neden olan bazı öğrencilerin başka liselere dağıtılmasını sağladı. Öğretmenler arasındaki tatsızlık kısmen azaltıldı ama halen soğukluk ve ayrışma devam etmekte ve bu durum okuldaki herkesi etkilemektedir.

Örnekolay 7 (Eğitim denetmeni): Bir ilçedeki okulda görev yapan bir okul müdürü, özverili çalışan gayretli bir eğitimcidir. Öğrencilerle ilgilenir, evlerine ziyaretler yapar, halkla ve esnafla diyalog kurar. Genelde sevilmesine ve takdir toplamasına karşın, farklı bir mezhebe mensup olduğu ve Cuma günü namaz saatlerinde camiye gitmediği için bazı öğretmen ve velilerin eleştirilerine maruz kalmaktaymış. Bu nedenle birkaç kez okulda tartışma yaşadığını öğrendim. Göreve halen devam eden müdür önyargılı yaklaşımları kırmakta zorlanmaktadır.

Örnekolay 8 (Okul yöneticisi): İlçedeki okulumuza atanan batı illerinde yetişmiş bir bayan öğretmen yetiştiği ildeki alışkanlıklarını ve yaşantısını devam ettirmeye çalışıyordu. Bu alışkanlıklarından biri de sabah sporuydu. Sabah sporuna çıkarken spor giyimi bu yörenin kültüründe rastlanmayan ve dikkat çeken şekildeymiş. Öğretmen sabah spor yaparken arkasına takılan gençlerin sayısı her gün artmaktaymış. Okulda da öğretmen ile ilgili algılamalar ve dedikodular oluşmaktaydı. Ayrıca nişanlısıyla birlikte aynı evde kalıyormuş. Bir gün öğretmen sabah sporu yaparken tacize uğramış. Şikâyetler üzerine tacizde bulunalar gözaltına alındı, kendisi hakkında da disiplin soruşturması başlatıldı. Öğretmen yaşadığı kültürel çatışmalar ve psikolojik travma sonunda öğretmenlikten istifa ederek okulumuzdan ayrıldı..

Örnekolay 9 (Öğretmen): Birkaç yll önce sendika üyesi bir öğretmen, üyesi olduğu sendikanın faaliyetleri ile ilgili yabancı ülke temsilcilerine medyada açılama yaptı. Okul müdürünün şikayeti üzerine öğretmen hakkında soruşturma açıldı ve açığa alındı. Fakat öğretmen 
mahkeme kararıla görevine geri döndü. Ancak okulda zaman zaman sıkıntılar yaşamaya devam etti. Okulda onu destekleyen öğretmenler ile karşı çıkanlar arasında da sıkıntılar yaşandı.

$\mathrm{Bu}$ çalışmada değerlendirmeye alınan örnekolayların beşi, farklılıkların neden olduğu sorunlara işaret etmektedir. Örnekolay 5, 6, 7, 8 ve 9'dan anlaşılacağı üzere, okullarda çalışanların farklılıkları, gerek okullar, gerekse çalışanlar ve okulun diğer paydaşları için sorun oluşturabilmekte, olumsuz sonuçlar doğurabilmektedir. Beşinci ve sekizinci örnekolaylarda kültürel altyapı, yaşam tarzı, davranış stili, gelenek, örf ve adet; altıncı ve dokuzuncu örnekolayda felsefi ve siyasi görüş; yedinci örnekolayda inanç gibi farklı bireysel özelliklere, farklı sosyo kültürel değerlere ve yaşam tarzına sahip öğretmenlerin çalıştığı okullarda anlaşmazlıklar, gruplaşmalar ve çatışmalar yaşanabileceğini göstermektedir.

\section{Tartışma ve Sonuç}

Okullarda farklılıklara ilişkin yönetici ve öğretmenlerle yapılan görüşmelerden ve denetmenlerin yürüttügü soruşturmalardan edinilen ve yukarıda kısaca aktarılan başarı ve sorun hikâyelerine göre okullarda genelde farklılıklar önemli görülmektedir. Farklı özelliklere sahip öğretmenlerin görev yapması yönetim, öğretmenler, öğrenciler ve okul açısından bazı avantajlar sağlarken özellikle okulun yönetimi açısından bazı zorlukları beraberinde getirmektedir. Yöneticiler okulu yönetme konusunda hesapta olmayan sıkıntılar yaşayabilmektedir.

Birinci ve üçüncü örnek olaylarda okulda erkek öğretmenlerin yanı sıra kadın öğretmenlerin görev yapması, özellikle kız öğrencilerle ilgili bazı sorunların çözümünü kolaylaştırdığı belirtilmiştir. Okullarda cinsiyete ilişkin farklılıklar örnekolaylarda olduğu gibi örgüte avantaj sağlayabilmektedir. İş yaşamında, çalışanların cinsiyetleri ile çeşitli örgütsel değişkenler arasındaki ilişki, birçok araştırmaya konu oluşturmuştur (Reder, 1978; Strober, 1982; Devanna, 1984; Olson \& Frieze, 1987; akt: Laçinler, 1997). Bu araştırmalarda; cinsiyetin iş performansını çok fazla etkilemediği, ancak, kadınların daha uyumlu ve erkeklerden daha az başarı beklentisi içinde oldukları rapor edilmiş, cinsiyet farklılıklarının 
istihdam fırsatlarında bir ayrımcılığa yol açmaması gerektiği ileri sürülmüştür (Schermerhon, Hunt, ve Osborn, 2000, 61-75; Akt: Balay ve Sağlam, 2004).

Diğer mesleklerde olduğu gibi öğretmenlikte de cinsiyet tartışmaları yapılmaktadır. Kimisi erkeklerin daha iyi öğretmenlik yaptığını, kimisi de öğretmenliğin feminen özellikler gerektirdiğinden kadın mesleği olduğunu savunmuştur. Bu bağlamda kimi yöneticiler belli bir cinsiyetteki öğretmenlerle çalışmayı tercih edebilmektedir. Cinsiyet en kadim tartışma konularından biridir. Eski çağlardan beri, kadınlar ve erkekler arasında doğanın belirlediği cinsiyetlerine dayanan farklılıktan ötürü daha çok kadınların aleyhinde bir ayrımcılık söz konusu olmuştur. Oysa önemli olan her iki grubun sahip olduğu üstün yönlerden azami ölçüde faydalanarak, birbirleriyle uyum içinde yaşamalarını sağlamaktır. $\mathrm{Bu}$ uyum belki günlük yaşamda daha kolay sağlanabilmektedir, ancak sorun özellikle iş hayatında yaşanmaktadır. Toplumda bireylerin yerine getirmeleri gereken görevlerin cinsiyetler arasında dağılımını ifade eden cinsiyet rolleri nedeniyle, bazı meslekler veya pozisyonlar kadın işi olarak tanımlanırken bazıları ise erkek işi olarak tanımlanmaktadır. Dolayısıyla cinsiyete dayalı ayrımcılık, en yaygın olarak iş ve çalışma yaşamı ile bu yaşama başlama koşullarının geliştirildiği eğitim ortamlarında tartışılmaktadır. Oysa örneğin kadınlar ve erkekler arasında problem çözme yeteneği, çözümleme becerileri, rekabetin sürdürülmesi, motivasyon, liderlik, sosyalleşme veya öğrenme yeteneği ile ilgili çarpıcı farklılıkların olmadığı belirtilmektedir (Öncer, 2004, 28).

Konrad ve Linnehan (1995) yaptıkları araştırmada, farklılıkların arttığı ve farklılıklara değer verilen örgütlerde özellikle kadınların işe devamsızlıklarının azaldığını ve performanslarının arttığını ortaya koymuşlardır. Ünal (2003), ilköğretim okullarında barış ortamının oluşturulmasına (gelişkin bir iletişim, sevgi, saygı, hoşgörü, empati kurabilme, önyargısız olabilme, kendisiyle barışık olma ve farklılıkların bir zenginlik olarak kabul edilmesi) kadın yöneticilerin katkısını incelediği araştırmada, okulda barışçı bir ortamın yaratılmasına kadın yöneticilerin olumlu katkılar sağladığına ilişkin görüş bildirenler, bunu daha çok kadınların hoşgörü, sabır, karşıdakini dinleme, şiddete başvurmama, 
dikkatli, titiz, düzenli olma ve ortamı yumuşatma gibi özellikleriyle açıklamışlardır.

İkinci ve dördüncü örnekolayda, farklı ilgi, yetenek ve yeterliklere sahip, farklı sosyo kültürel çevrelerden gelen öğretmenlerin okullarda görev yapmasının, okulların amaçlarına ulaşmasını kolaylaştırdığı gibi okulun ve öğrencilerin gelişimine daha çok katkı sağlayabildiği bulgusuna ulaşılmıştır. Watson, heterojen grupların, sorunları tanımlama ve çözüm üretmede homojen gruplara göre daha etkin olduğunu belirtmektedir (Akt: McMahan, Bell ve Virick, 1998, 200). Nitekim bu hikâyelerde bayan öğretmenin varlığı ya da farkı yöresel bir dili bilmenin, öğrencilerin sorunlarını anlamada ve çözüm sağlamada ne denli önemli olduğu görülmektedir. Bayan öğretmenin okulda görev yapmasının, folklor ekibindeki kız öğrencilerin il dışındaki yarışmaya katılımını kolaylaştırabildiği düşünüldüğünde, bu farklılıkların okullarda yöneticilerin işini kolaylaştırdığı görülmektedir. Araştırmalar işgücü profilinde farklılaşmanın rekabet gücünü sürdürmek için gerekli olan farklı becerilerin örgüt bünyesinde toplanmasını sağladığını ortaya koymuştur (Gilbert, Stead ve Ivancevich, 1999).

Yapılan başka araştırmalarda da örgütlerde işgücü farklılıklarının yararları ortaya konmuştur. $\mathrm{Bu}$ araştırma bulgularına göre iyi yönetildiğinde çalışanlara ilişkin farklılıkların sağladığı potansiyel bazı avantajlar şöyle sıralanmıştır: En iyi yetenekleri örgüte çekme ve örgüt içinde tutma; grup düzeyinde problemlere alternatif çözümler geliştirme yeteneği kazanma (Nemeth, 1986); çevresel değişime karşı daha hızlı tepki gösterme ve daha yüksek düzeyde uyum sağlama yeteneği kazanma (Clarge, Cao ve Lahenay, 2003); rekabet etme; çalışan etkililiğinin yükseltilmesi, çalışanlar arasında iletişimi artırma; yüksek düzeyde bireysel ve örgütsel öğrenme, yaratıcılık ve yenileşme (Mollica, 2003); takım çalışması ve sinerji; çok kültürlü ilişkiler geliştirme (Glaman, Jones, ve Rozelal, 1996); daha etkin karar alma ve sorun çözme yeteneği kazanma; çalışanların morallerini, işdoyumunu ve örgütsel etkililiği artırma (Gilbert ve Stead, 1999); iş bırakma ve işe devamsızlıkta azalma (Cox ve Smolinski, 1994); tüm toplum kesimleriyle daha iyi ilişkiler ve olumlu örgütsel imaj (McMahan, Bell ve Virick, 1998). 
Farklılığın, problem çözme ve karar almada getirdiği bazı avantajlar vardır. Bünyesinde farklı kimlikler barındıran gruplarda, problemlere yaklaşım daha geniş ve zengin bir bakış açısıyla olacak, analizler ve değerlendirmeler daha sağlıklı yapılacaktır. Nemeth ve Wachter'in (1983) yaptığ 1 araştırmada, gruplar içindeki farklılıkların daha çok alternatifler üretilmesini ve varsayımlar üzerinde daha geniş ve kapsamlı araştırmalar yapılmasını sağladığı görülmüştür (Akt: Cox, 1992).Gruplar içindeki farklılıklar sayesinde daha çok alternatifler üretilebilir ve varsayımlar üzerinde daha geniş ve kapsamlı araştırmalar yapılabilir. Araştırmalar problem çözmede heterojen grupların homojen gruplara göre daha başarılı ve yaratıcı olduklarını göstermektedir (Cox, 1992).

$\mathrm{Bu}$ çalışmada değerlendirmeye alınan örnekolayların beşi, farklılıkların neden olduğu sorunlara işaret etmekte, farklı bireysel özelliklere, farklı sosyo kültürel değerlere ve yaşantıya sahip öğretmenlerin çalıştığı okullarda anlaşmazlıklar, gruplaşmalar ve çatışmalar yaşanabildiğini göstermektedir. Bu durum özellikle okul yöneticilerinin yönetsel karar ve uygulamalarını zorlaştırabilmektedir. Görüşme yapılan kimi yöneticilerin farklılıklara mesafeli yaklaştığı̆, bu yaklaşımın temelinde bu kaygıların yattığı söylenebilir.

Tüm örgütlerde olduğu gibi okullarda da farklıklar, iyi yönetilmediğinde kimi zaman bazı sorunları da beraberinde getirmektedir. Alanyazında da farklılıkların örgütlerde yaratabileceği potansiyel sakıncalara ilişkin çalışmalar önemli yer tutmaktadır. Araştırmalar, farklılıkların örgütte iletişimi güçleştirdiğini ortaya koymuştur. $\mathrm{Bu}$ araştırmalarda, kültürel açıdan homojen gruplarda iletişimin, heterojen gruplara göre daha kolay gerçekleştiği, grup içindeki farklılıklardan dolayı yanlış anlamaların, fikir ayrılıklarının ve huzursuzlukların yaşandığı belirlenmiştir (Fiedler, 1966; Akt: Laçinler, 1997; Milliken ve Martins, 1996; Williams ve O'Reilly, 1998). İnsanlar çeşitli açılardan kendileri ile benzer gördükleri insanları kendilerine daha yakın görürler ve başkalarına nazaran bunlarla daha rahat iletişime geçerler. Çünkü bunlarla paylaşacakları ortak değerleri daha fazla olduğundan daha iyi anlaşabileceklerini düşünürler. Örneğin iki farklı ülkeden/ulustan insanlar üçüncü bir ülkede bir araya geldiklerinde genellikle aynı ulustan olanlar birbirlerine daha yakınlık duyarlar. Aynı şekilde bir örgütte, aynı bölgeden 
olan insanlar ya da aynı felsefi görüşü /ideolojiyi paylaşan kimseler daha rahat diyalog kurarlar. Ancak yapılan başka araştırmalara göre, aralarında farklıklılar bunan çalışanlar uzun süre birlikte çalışınca ve aynı ortamı paylaşınca zamanla, özellikle demografik farklılara ilişkin hassasiyetleri azalmaya, buna karşın sosyal ve kültürel değerlere ilişkin duyarlıkları güçlenmeye başlar (Glaman, Jones, Rozelal,1996; Harrison, Price, Bell, 1998).

Alvarez ve Jakson'a göre (1994) farklılık, gruba ve örgüte bağlılığ azaltıcı bir etkendir. Ancak araştırmalarda farklılıklar ve bağlılık arasındaki ilişki ile ilgili farklı sonuçlara ulaşılmıştır. Bu araştırmalarda Cox (1992), gruptaki homojenliğin grup bağlılığını artırdığını ve yüksek grup bağlılığının da düşünceleri tekdüzeleştirdiğini; Gilbert ve Ivanchevich (2001), farkl1lıkların daha yoğun olduğu çokkültürlü örgütlerde örgütsel bağlılığın daha yüksek olduğunu; Tsui, Egan ve O'Reilly (1992) ise, örgütlerde artan farklılığın örgütteki çoğunluk grubun bağlılığını olumsuz etkilediğini ortaya koymuşlardır. Okul ve diğer eğitim kurum yöneticileri üzerinde yapılan araştırmada, görüşme yapılan eğitim liderlerinin bazıları, farklı kültürel arkaplandan gelenlerin oluşturduğu bir grubu /takımı yönetmenin daha zor olduğunu ve bu nedenle takımların benzer özelliklere sahip kimselerden oluşturulması gerektiğini savunmuşlardır (Maldonado, Dreachslin, Dansky, Souza ve Gatto, 2002).

$\mathrm{Bu}$ çalışmada beşinci, altınc1, yedinci, sekizinci ve dokuzuncu örnekoalaylarda, yaşam tarzı, inanç ve felsefi görüş farklılıklarının okullarda sorun ve çatışma kaynağı olabileceği bulgusuna ulaşılmıştır. Örgütlerde farklılıklar, kırılma ve çatışmanın kaynağı olabilir (Resenzweig 1998, 647). Sosyo-kültürel farklılıkların baskın olması ve kötü yönetilmesi; çalışanların stresinin yükselmesi ve çatışma ortamının büyümesine, morallerin düşmesine, verimlilik ve kalite sorunlarına ve iş kazalarının artmasına yol açabilir (Loosemore ve Lee 2002, 517; akt. Balay ve Sağlam, 2004). İçinde kültürel açıdan farklılıklar gösteren grupların olduğu örgütlerde çatışmaların yaşanması kuvvetle muhtemeldir. Çatışma, genel eğilim olarak örgütte istenmeyen bir durumdur. Çünkü örgütsel ilişkileri, ahengi ve uyumu bozmasından korkulur. Ancak çatışma kimi zaman da istenilen durumdur ve farklılıkların avantajları en iyi şekilde kullanılarak iyi yönetildiğinde örgütsel gelişmeye katkı sağlayabilir. 
Çalışmada altıncı ve dokuzuncu örnekolayda felsefi ve siyasi görüş; yedinci örnekolayda inanç (mezhep) farklılıklarının okullarda yarattı̆̆ olumsuzluklar ile ilgili alanyazında çeşitli çalışmalar mevcuttur. Felsefi düşünce ve din, bireylerin ve toplumların yaşam tarzlarını düzenlemede önemli bir yer tutar. Dinler, uygulama şekilleri değişmekle beraber tüm toplumlarda mevcuttur ve kültürü oluşturan unsurlardır. Örgütlerde genellikle bireylerin dini inançlarını vurgulayan davranışlarda bulunmaması istenir. Ancak dini kimlik, işyeri girişinde kapıya teslim edilecek bir değer değildir. Bu sebeple de, örgütlerde çalışan bireylerin mensup oldukları dini sistemlerden kaynaklanan farklılıklar önemli ve hassas bir konudur (Öncer, 2004, 59). Bireylerin sahip olduğu inanç ve tutumlar, iş hayatlarını etkileyebilmektedir. Özellikle farklı kültür, din ve mezheplerden insanların bulunduğu toplumlarda bu inanç ve değerler, işyerinde bir sorun oluşturabilmektedir. Bu nedenle, bazı yöneticiler iş ortamında dini çatışmalar ve krizler yaşanmasını engellemek düşüncesiyle işyerlerini "dinden arındırılmış" olarak ilan etmektedir. Her ne kadar dini inançlar kanunlarla koruma altına alınmışsa da, çalışanlar işyerlerinde inançlarından dolayı ayrımcılığa maruz kalabilmektedirler (Rivera, 2001; akt. Öncer, 2004, 62).

Adler'e (1991) göre, örgütlerde işgörenlerin dil, fikir, değer, inanç gibi kültürel farklılıklar ile ırk ve etnik köken gibi demografik farklılıkları; onların ve grubun öğrenmesi, gelişmesi ve etkililiği üzerinde olumlu etkisi vardır. Örgütte farklı olanlar sadece kendi gruplarının içerisinden enformasyon getirmezler, işlerin nasıl yapılacağı, proseslerin nasıl tasarlanacağı, hedeflere nasıl ulaşılacağı, görevlerin nasıl formüle edileceği, etkin ekiplerin nasıl oluşturulacağ liderlik edileceği konusunda farklı, önemli ve rekabet açısından değer taşıyan bilgi ve perspektifler getirirler. Bu farklı bilgi ve perspektifler örgütteki bireylerin bilgi ve becerilerini geliştirdiği gibi, imkan sağlandığında bu grupların mensupları, örgütün işlevleri, stratejileri, faaliyetleri, uygulamaları ve işleyiş kuralları konusunda temel varsayımları sorgulamak suretiyle örgütlerin büyüyüp gelişmesine katkı sağlayabilirler (Thomas ve Ely, 1999).

Örgütler ve çalışanlar açısından dini inançlardan kaynaklanan sorunlar şu şekilde yaşanabilmektedir (Benent, 2001; akt. Öncer, 2004, 63): 
Çalışanların gün içinde ibadet saatlerinde ara almalarına izin verilmemekte; dini inanç nedeniyle başörtüsü gibi bazı dini kıyafetlerin giyilmesi sorun yaratabilmekte, bunları giyen ya da takanlarla dalga geçilebilmekte, dışlanmakta; dini inancı yansıtan kıyafet ya da semboller, bunları benimsemeyen azınlıklar üzerinde psikolojik bir baskı yaratabilmektedir. Dinsel önyargının ya da dışlamanın olduğu örgütlerde performans kaybı kaçınılmaz olur. Buna maruz kalan çalışanlar kimi zaman işyerini değiştirmekte ya da işten ayrılmak durumunda kalmaktadır. Bu durum aslında örgütler için de verimlilik kaybı, yetenekli elemanı kaybetme gibi sorunlara yol açabilir. Örgütlerde dini inanç ve değerlere saygılı politikalar uygulanırsa, bireyler felsefi görüşleri ve inançları yüzünden ayrımcılığa maruz kalmaz, motivasyonları, işdoyumları ve verimlilikleri artar. Bundan hem çalışanlar, hem de örgüt kazançlı çıkar.

Sonuç olarak başarı ve sorun hikâyeleri değerlendirildiğinde diğer tüm örgütlerde olduğu gibi okullarda da çalışanlara ait farklılıkların hem entellektüel gelişim, hem de okuldaki bazı sorunlara pratik çözümler getirme açısından önemli avantajlar sunduğu, ancak bunun yanında kimi sorunlara da neden olduğu görülmektedir. Örnek olaylardaki sorun hikâyelerine bakıldığında farklılıkların özellikle okulun yönetimi açısından bazı zorlukları beraberinde getirdiği, yöneticilerin okulu yönetme konusunda hesapta olmayan sıkıntılar yaşayabildiği görülmektedir.

Farklı yetişme koşullarından ve kültürel arkaplanlardan gelen insanlar kendileri olma özgürlüklerine sahip olmak ve bunu kullanmak isterler. Farklı olmak; her insanın kendine özgü bakış açısı, ilkeler bütünü, güçlü ve zayıf yanları ve insanlararası ilişkileri olması anlamına gelir. Bu farklı özellikler herkes için ayrı niteliktedir ve kişiyle özdeşleşmiş bir yapıdadır. Kişi çalışma ortamında sahip olduğu niteliklerinden vazgeçmeden, ancak diğer insanların niteliklerine de saygı göstererek farklı olmayı sürdürür. Bu açıdan farklılık, örgütler için hem bir avantaj hem de sorun çıkarıcı bir olgu olarak kendini gösterir. Okullarda da işgücü farklılıkları örgütsel açıdan çeşitli avantajlar sağlarken aynı zamanda kimi sakıncalara da yol açabilmektedir. Bu sakıncaların savuşturulması, farklılıkların bir zenginlik olarak görülmesine ve onların iyi yönetilmelerine bağlıdır. 


\section{Kaynakça}

Adler, N. J. (1991). International dimensions of organizational behavior. Boston, MA: PWS-KENT.

Alvarez, E. B. \& Jackson, S. E. (1992). Working through diversity as a strategic imperative, in S. E. Jackson (ed.), Diversity in the workplace. the guilford press New York.

Ashkanasy, N. M., Hartel, C. E. J ve Daus, C. S. (2002). Diversity and emotion: The new frontiers in organizational behavior research. Journal of management (28): 3, 307-338.

Balay, R. ve Sağlam, M. (2004). Eğitimde farklılıkların yönetimi ölçeğinin uygulanabilirliği, Burdur: SDÜ Burdur eğitim fakültesi dergisi, Y1l: 5, Say1: 8, 32-46, Aralık-2004.

Begeç, S. (2004). Farklılıkların yönetimi ve Genel Kurmay Başkanliği bariş için ortaklik merkezinde yapilan bir araştirma, Marmara Üniversitesi Sosyal Bilimler Enstitüsü (Yayımlanmamış Doktora Tezi), İstanbul.

Bhadury, H.; Mighty, E. J. ve Damar, H. (2000). Maximizing workforce diversity in project teams: a network flow approach. The International journal of management science (28): 143-153.

Clarge, S., Cao, G., ve Lahenay, B. (2003). Diversity management in organizational change towards a systemic framework. Systems research and behavirioal science, 20, 231-242

Cox, T. ve Nkomo, S. M. (1990). Invisible men and women: a status report on race as a variable in organization behavior research. Journal of organizational behavior. 11, 419-431.

Cox, T. (1992). Cultural diversity in organizations, San Francisco, Berrett - Koehler Publishers. 
Cox, T. J., ve Blake, S. (1991) Manging cultural diversity: Implications for organizational competitiveness. Academy of management executive, 5 (39), 45-55.

Demovsky, S. ve Niemuth, J. (1999). The global classroom: a study in appreciation, awareness and acceptance of different cultures and people in ever changing world. Saint Xavier University \&IRI Skylight Field Based Masters Program, Illinois.

Gentile, M. C. (1994). Differences that work - organizational excellence through diversity. Boston: Harvard Business School Press.

Gilbert, J. A. ve Ivanchevich, J. M. (2001) Effects of diversity management on attachment. Journal of applied social pshychology,31 (7), 1331-1349.

Gilbert, J. A. ve Stead, B. A. (1999). Stigmatization revisited: Does diversity management make a difference in applicant succes? Group \& organization management, 24 (2), 239-256.

Glaman, J. M., Jones, A. M. ve Rozelal, R. M. (1996). The effects of co-worker similarity on the emergence of affect in work teams. Group \& organization management, 21 (2), 129-215.

Harrison, D.A., Price, K.H. ve Bell, M.P. (1998). Beyond relational demography: Time and the effects of surface -and deep- level diversity on work group cohesion. Academy of management journal, 41 (1), 96-107.

Heilman, M. E. (1994). Affirmative action: some unintended consequences for working women. Research in organizational behavior, 16, 125-169

Kaptan, S. (1991). Bilimsel Araştırma ve İstatistik Teknikleri. Ankara, Rehber Yayınevi

Konrad, A. M., ve Linnehan, F. (1995). Formalized HRM structures: Coordinat $\neg$ ing equal employment opportunity or concealing organizational practices? Academy of management journal, 38, 787-820. 
Laçinler, E. K. (1997). İnceleme: Farklılıkların ve Benzerliklerin Yönetimi. HR Dergi. 2

Loosemore, M ve Al Muslmani, H. S. (1999). Construction project management in the Persian gulf: inter-cultural communication. International journal of project management, 17 (2), 95-100.

Maldonado, R. W., Dreachslin, J. L., Dansky, K.H., Souza, G. ve Gatto, M. (2002). Racial/ethnic diversity management and cultural competency: the case of Pennsylvania hospitals. Journal of healthcare management. 47, 2 (March-April): 111-124.

McMahan, G. C.; Bell, M. P. ve Virick, M. (1998). Strategic human resource management: employee involvement, diversity, and international issues. Human resource management review, 8 (3), 193-214.

Milliken, F.J., ve Martins, L.L. (1996). Searchinf for common threads: understanding the multiple effects of diversity in organzationl groups. Academy of management review, 21 (2), 402-433.

Mollica, K. A. (2003). The influence of diversity context on white men's and racial minorities' reactions to disproportionate group harm. The journal of social psychology, 14 (4), 415-431.

Muter, Ş. (1999). Endüstri ilişkilerinde kültürel etkenler ve sendikalarin yeni rolü. http://www.tisk.org.tr/isvederg/temm2000/endustr.htm (erişim: 26.12.2003)

Nemeth, C.J. (1986). Differential contributions of majority and minority influence. Psychological Review, 93, 23-32

Öncer, A. Z. (2004). İşletmelerde Bireysel, örgütsel, yönetsel farklilik kaynaklari ve farklilaşma stratejileri: unilever unity projesi kapsaminda bir araştirma. Marmara Üniversitesi Sosyal Bilimler Enstitüsü (Yayımlanmamış Doktora Tezi), İstanbul.

Punch, K. F. (2005) Sosyal araştirmalara giriş. Çev: D. Bayrak, H. B. Arslan, Z. Akyüz. Ankara, Siyasal Kitabevi 
Richard, O. (2000). Racial diversity, business strategy and firm performance: A resource based view. Academy of management journal, 43 (32), 164-177.

Richard, O., McMillan, A., Chandwick, K., ve Dvyer, S. (2003). Employing an innovation strategy in racially diverse workforces. Group and organization management. 28, 1 (March): 107-126

Ricucci, N. M. (1997). Cultural diversity programs to prepare for workforce 2000: what is gone wrong? Public personel management, 26, 3542 .

Schermerhon, J. R., Hunt, J. G., ve Osborn, R. N. (2000). Organizational behavior. 7th Ed. John Wiley \& Sons Inc. New York.

Speechley, C. ve Wheatley, R. (2001). Developing a culture for diversity in a week. HodCer \& Stoughton, London.

Thomas, D. A. ve Ely, R. J. (1999). Farklılıklara önem kazandırmak: çeşitliliği yönetmek için yeni bir paradigma. İnsanları yönetmek. (Harvard business review). Çev: G. Bulut, İstanbul: MESS Yayınları.

Tsui, A., Egan, T. ve O'Reilly, C. (1992). Being different: Relational demography and organizational attachment. Administrative science quarterely. 37: $\quad 549-579$

Ünal, L. I. (2003). İlköğretim okullarında demokratik okul ortamının oluşturulmasına kadın yöneticilerin katkısı. Eğitim Bilim Toplum Dergisi, 1 (2/3). Ankara.

Von Bergen C.V., Soper B. and Foster T. (2000). Unintended negative effects of diversity management, Public personal management, 3 (2), 239-252.

Watson, W. E., Kumar, K. ve Michaelson, L. K. (1993). Cultural diversity's impact on interaction process and performance: Comparing homogeneous and diverse task groups. Academy of Management journal, 36 (3), 590-602. 
Williams, K. ve O'Reilly, C. (1998). Demography and diversity in organizations: A review of 40 years of research. Research in organizational behavior, 20, 77-140.

Wochner, R. (1963), Educational research methods. New York: The Ronald Pres Co.

Wright, P.M. ve McMahan, G.C. (1992). Theoretical perspectives for strategic human resource management. Journal of management, 18, 295320 .

\section{EXTENDED ABSTARCT}

Rapidly changing demographic and economic structures in the world, globalization and technological developments affect organizational philosophies, cultures and strategies and increase organizational diversity. Knowing the fact that such mentality changes in organizations feature human kind as the core of competition and place individuals in the centre (Bhadury, Mighty and Damar, 2000, 143), there is a need for management styles and new approaches to interpersonal relationships. In this context, one of the newly emerging approaches is diversity management.

As organizations geographically extend and international free movement of labor force increases, interactions with broader identities and diversity have gradually become critical and thus caused constant changes in labor force composition (Ashkanasy, Hartel and Daus, 2002, 308). Major diversity factors between organizational staff could be listed as follows:

Demographic diversity: Demographic diversity includes constant or permanent features such as race, nationality, ethnic origin, gender, age, experience, place of birth or place where employees feel they belong and physical features (physical fitness for work). Socio-cultural diversity: This includes already existing or adopted values such as religion, and philosophical belief, political view, educational background, economic level, way of thinking, cultural background, lifestyle, customs and traditions and values. Diversity in personal features: It includes character, physical and mental abilities, skills and knowledge, behavioral style, 
psychological, spiritual and emotional nature, individual conceptualization and emotional adaptation.

Diversity among people is something natural and common. Everybody has different demographic, individual and socio-cultural features and values. Such diversity may have various organizational reflections, individual and organizational advantages and disadvantages. Labor force diversity brings certain organizational benefits, whereas it might cause some disadvantages when it is not well-managed. In this sense, diversity is a phenomenon that leads to both advantages and disadvantages for organizations. It is important to be aware of such pros and cons.

Employees of educational organizations, as in other fields, have different demographic, social, cultural and personal features and it is important to manage such differences well with regard to individual and organizational goals. Despite this fact, it could be said that the number of studies on differences, especially in education, is not satisfactory in Turkey. In this context, the purpose of the research is to determine the views of teachers and administrators concerning the (positive and negative) consequences arising from the diversity related to employees at high schools.

\section{Method}

A survey research methodology was employed in the study. Case study, a qualitative method, was used for data gathering. For this, in the study; administrators, teachers and supervisors were interviewed about experienced problems or success stories in the schools related to the issue and investigation documents were examined. Case studies were based on qualitative data from the interviews or document examinations (Wochner, 1963, 99; Kaptan, 1991, 66-69; Punch, 2005, 145).

The target population of the research consisted of state high school teachers, administrators and educational supervisors in Kayseri and Van central provinces, a city in the central Anatolia region of Turkey and a city in the Eastern Anatolia Region of Turkey respectively. Considering the number of the high schools and the populations of the two cities, 
administrators and teachers from four high schools in Kayseri (two administrators and two teachers from each school), administrators and teachers from three high schools in Van (two administrators and two teachers from each school) and three educational supervisors from each city were included in the research group. Thus, the research group consisted of 14 high school administrators, 14 high school teachers and 6 educational supervisors.

"Content analysis", a qualitative analysis method, was used for data analysis. Content analysis, a systematic analysis of written and oral materials, is categorization and definition of encodings for what people say (Balc1, 2001, 209; Yıldırım and Şimşek, 2005, 227; Neuendorf, 2002, 1-9; Neuman, 2007, 663-666). Content analysis has qualitative and quantitative methods. In quantitative content analysis, the repetition (frequency) of statements (sentences) by participants is determined. However, in qualitative content analysis, statements are evaluated according to their qualities as positive, negative or neutral. In the study, qualitative descriptive content analysis was employed. Accordingly, the tape-recorded or noted stories in the interviews were deciphered and later defined by categorization: positive (success story) and negative (experienced problems). Finally, they were evaluated by inductive method.

\section{Result}

According to the success stories and experienced problems from the interviews with administrators and teachers about diversity in schools and investigations by supervisors, diversity is taken seriously in schools. Employing teachers with different features brings certain advantages for administration, colleagues, students and schools, but it also causes some difficulties for school administration. As a result, it is obvious that diversity related to school staff offers advantages in terms of bringing some practical solutions to both problems at schools and problems concerning intellectual development, but it also causes problems particularly for school administration. Thus, school administrators could experience unexpected problems in school administration. 
Individuals from different upbringings and cultural backgrounds would like to have personal freedom and use their right to freedom. Being different means a unique way of understanding, a set of principles, having strengths and weaknesses, and interpersonal relationships. Different features mean separate things for everyone and they are a part of individuals. One continues to be different without giving up his own features in workplace, but he has to respect others' features. In this sense, diversity is both an advantageous and disadvantageous phenomenon for organizations. Labor force diversity in schools offers certain advantages for educational organizations, but it also causes some problems. Avoiding such disadvantages depends on taking diversity as a rich source and managing it in a good way. 